\title{
Dermal Pathology in Melasma: An Update Review
}

\section{Kachanat Phansuk (D) \\ Vasanop Vachiramon (D) \\ Natthachat Jurairattanaporn (D) \\ Kumutnart Chanprapaph (D) \\ Teerapong Rattananukrom (i)}

Division of Dermatology, Department of Medicine, Faculty of Medicine

Ramathibodi Hospital, Mahidol

University, Bangkok, Thailand
Correspondence: Teerapong

Rattananukrom

Division of Dermatology, Department of Medicine, Faculty of Medicine,

Ramathibodi Hospital, Mahidol University,

270 Rama VI Road, Rajthevi, Bangkok,

10400, Thailand

Tel $+662-201-|| 4 \mid$

Fax $+662-201-1211$

Email teerpongrattananukrom@gmail.com
Background: Melasma is a complex and multipathophysiological condition that is challenging to treat. The roles of each element in the dermis were highlighted in this recent year due to targeting it with emerging therapies. Although some studies have demonstrated abnormal findings in the dermis of melasma lesions, there are no integrated data regarding these findings. Purpose: This article aims to discuss each finding in the dermis of melasma lesions and to provide some ideas about treatment options.

Methods: An Internet search was completed using the MEDLINE, Embase, Scopus, and Google Scholar databases for relevant literature through June 2021 and reference lists of respective articles. Only the articles published in English language were included.

Results: Several studies have focused on the dermal changes in melasma. Common findings included basement membrane disruption, pendulous melanocytes, marked solar elastosis, increased melanophages, increased mast cells, and neovascularization. In addition, each of them had the specified mechanism that may relate with the others.

Conclusion: Several changes in the dermis of melasma lesion may be connected with pathological changes in the epidermis. This may serve as a potential target treatment for melasma, which requires a multimodal approach.

Keywords: basement membrane, chloasma, hyperpigmentation, mast cell, photoaging, pigmentation disorder, solar elastosis

\section{Introduction}

Melasma is a common hyperpigmentary condition with multiple etiologies. Despite the fact that melasma is clinically characterized by epidermal hyperpigmentation, the histopathological changes involve both the epidermis and dermis. In addition, the pathogenesis of melasma is complex and includes both exogenous and endogenous factors. Regarding histopathological findings, there are several changes in melasma lesions compared to nonlesional skin. As expected, there was more melanin in all epidermal layers, and some epidermal thinning was observed. ${ }^{1}$ Several studies have demonstrated dermal change pathology within melasma. The aim of this review is to discuss the abnormalities in the dermis of melasma lesions (Figure 1) and demonstrate the roles for each cells involved in dermal pathologic process in association with biological or signal pathway (Table 1). In addition, this review also provide some ideas about treatment options for this difficult-to-treat condition.

\section{Basement Membrane Disruption}

The basal basement membrane of melasma patients has been found to have a vacuolar structure within keratinocytes and tends to contain large numbers of single, nonaggregated melanosomes. ${ }^{2}$ A total of $95.8 \%$ of melasma lesions exhibited damage to the basal membrane, and $83 \%$ had an antibody to collagen type IV. ${ }^{3}$ 


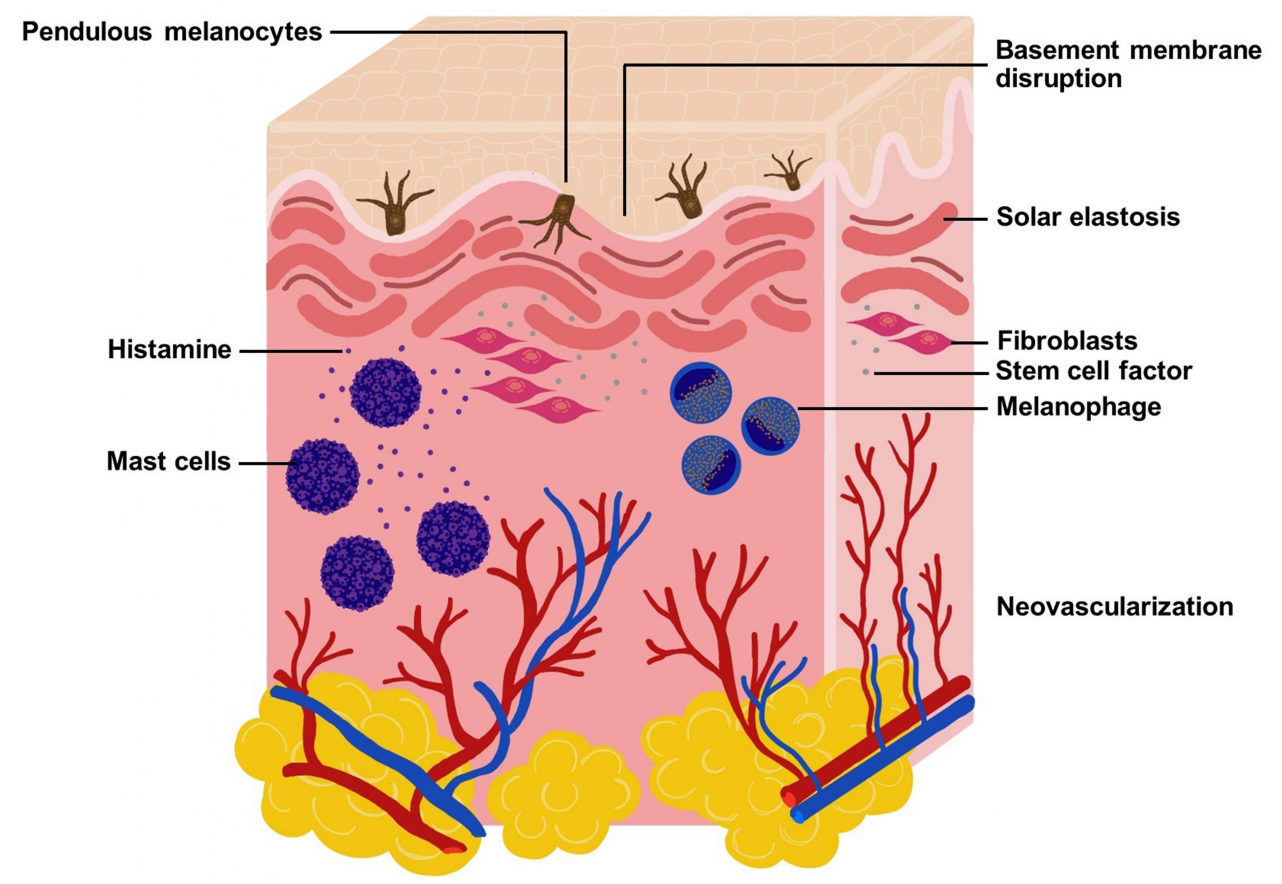

Figure I Diagram demonstrated pathologic changes in the dermis of lesional melasma including basement membrane disruption, pendulous melanocytes, melanophages, mast cells, stem cell factor, solar elastosis, and neovascularization.

In some studies, the basement membrane was observed to protrude into the dermal layer, but when compared to the immunohistochemistry results, these cells were compatible with melanocytes. ${ }^{4}$ The reason above implies that disruption can also cause melanocytes to migrate into the dermal layer and lead to constant hyperpigmentation in melasma (Figure 2A).
In UV-induced photoaging, there are activated forms of matrix metalloproteinases (MMP-2 and MMP-9), known as gelatinase. Gelatinases are the specific degraded enzymes of type IV collagen and type VII collagen, which are components of the epidermal basement membrane. ${ }^{5}$ In the same way, the reason above might explain the cause of basement membrane disruption.

Table I Cell Differentiation in Dermal Pathology in Melasma

\begin{tabular}{|l|l|l|}
\hline Cells & \multicolumn{1}{|c|}{ Definition } & Role of Each Cell Involved in Dermal Pathologic Process \\
\hline $\begin{array}{l}\text { Pendulous } \\
\text { melanocytes }\end{array}$ & $\begin{array}{l}\text { - Melanocytes that protrude into the dermal layer and } \\
\text { related to the hyperactivity of melanocytes }\end{array}$ & $\begin{array}{l}\text { - Loss of basement membrane and cadherin expression by chronic } \\
\text { UV exposure lead melanocytes to migrate deeper into the dermis }\end{array}$ \\
\hline Melanophages & - Melanin-containing macrophages & $\begin{array}{l}\text { - The phagocytized melanin in cytoplasmic granules within dermis } \\
\text { layer leading to persistent of pigmentation }\end{array}$ \\
\hline Fibroblasts & $\begin{array}{l}\text { - Dermal resident cells, which can produce collagen and } \\
\text { other fibers }\end{array}$ & $\begin{array}{l}\text { - Upregulate the tropoelastin mRNA gene expression and elastin } \\
\text { production by chronic UV radiation } \\
\text { - Overexpress the cadherin II resulting in an increase of MMP-I } \\
\text { and MMP-2 expression and basement membrane disruption } \\
\text { - Increased expression of stem cell factor }\end{array}$ \\
\hline Mast cells & $\begin{array}{l}\text { - Inflammatory cells that mediate inflammatory responses } \\
- \text { The granules contain of several cytokines such as tryptase } \\
\text { and histamine, which can be stimulated by the UV exposure }\end{array}$ & $\begin{array}{l}\text { - Tryptase can activate the pro-collagenase enzymes leading to } \\
\text { collagen degradation and elastotic materials } \\
\text { - Produce VEGF leading to neovascularization } \\
\text { - Produce inflammatory mediators such as TNF- } \alpha, \text { TGF- } \beta \text {, IL-8 }\end{array}$ \\
\hline
\end{tabular}

Abbreviations: IL-8, interleukin-8; MMP, matrix metalloproteinase; mRNA, messenger ribonucleic acid; TGF- $\beta$, transforming growth factor- $\beta$; TNF- $\alpha$, tumor necrosis factor- $\alpha$; UV, ultraviolet; VEGF, vascular endothelial growth factor. 


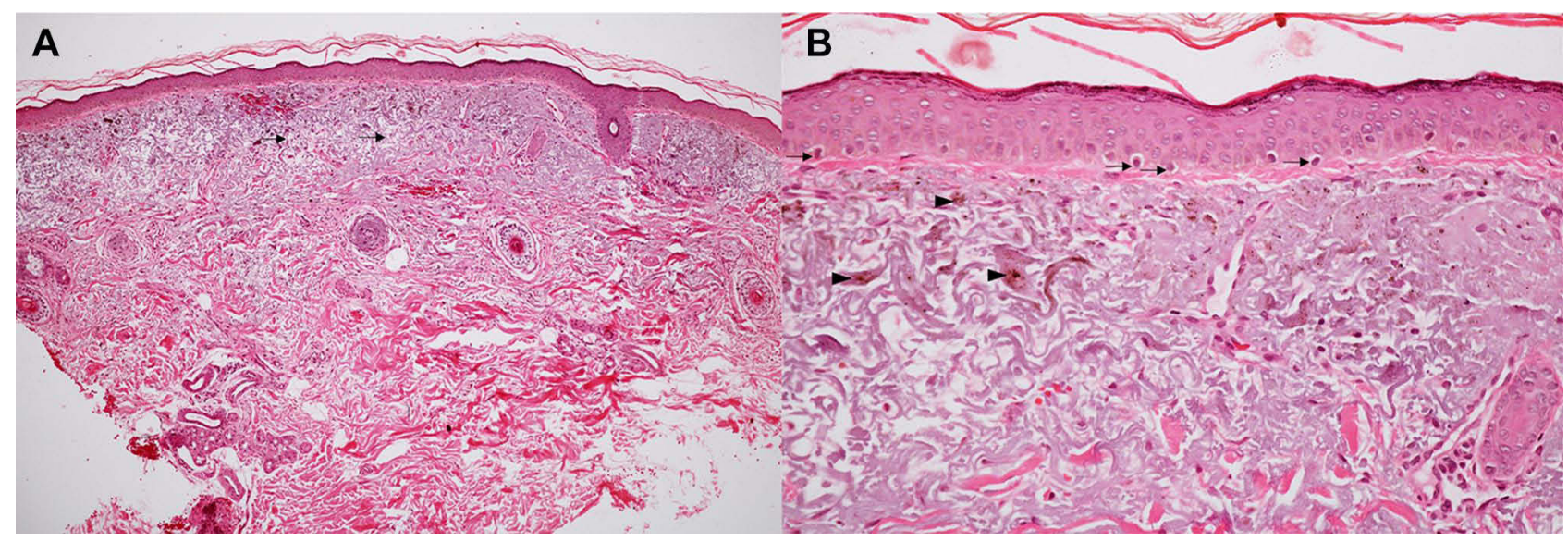

Figure 2 Histopathologic change in the dermis of lesional melasma. (A) Melanin deposition in the epidermis and solar elastosis in the dermis (arrow) (Hematoxylin and Eosin, HExI00) (B) pendulous melanocytes in the basal layer of epidermis (arrow) and increased dermal melanophages (arrowhead) (HE x400).

Cadherin 11 was suspected to be the key to basement membrane disruption in melasma. Cadherin 11 (CDH11) is expressed in dermal fibroblasts and keratinocytes but not in melanocytes. Overexpression of CDH11 in fibroblasts increases matrix metallopeptidase (MMP-1 and MMP-2) expression in fibroblasts and MMP-9 expression in keratinocytes. Accordingly, the increase in MMP-2 and MMP-9 activities could degrade type IV collagens and disrupt the basement membrane. In the same way, MMP-1 also destroys type I collagen in the dermal layer. ${ }^{6}$

\section{Pendulous Melanocytes}

The term pendulous melanocytes refers to melanocytes that protrude into the dermal layer (Figure 2B). The mechanism of this phenomenon has not been well elucidated, but some pieces of evidence have shown that they are related to the hyperactivity of melanocytes. Moreover, the means of basement membrane disruption were discussed in reference to the effect of this event. The loss of the basement membrane is a result of the increase in MMP-2 expression, which may be influenced by chronic UV exposure. ${ }^{3}$ In addition, cadherin mediates the process of adhesion between keratinocytes and melanocytes for intercellular signaling. Once melanocytes lose their cadherin expression due to chronic UV exposure, keratinocytes cannot control them. Melanocytes can then migrate deeper into the tissue below. ${ }^{7}$

According to a previous study that tried to demonstrate the effect or position of melanocytes after UV irradiation, low doses $\left(20 \mathrm{~J} / \mathrm{cm}^{2}\right)$ of UVA1 (340-400 nm) caused pendulous melanocytes to protrude into the dermis without losing contact with the basement membrane. In comparison, higher doses (60 $\mathrm{J} / \mathrm{cm}^{2}$ ) led to the migration of melanocytes into the dermis, which could be detected more than four years later. ${ }^{8}$ The term pendulous melanocytes, referring to the hyperactivity of melanocytes, was indirectly found in one study. That study aimed to specify the histology and ultrastructure of café au lait spots, one of the abnormal dermal hyperpigmentary disorders. Interestingly, the results revealed numerous pendulous melanocytes, while an observation of ultrastructure using electron microscopy was performed at the subcellular level and depicted the unique characteristics of pendulous melanocytes. These distinct cells also contained increased lipid droplets, mitochondrial dilatation, and melanosomal autophagic vacuoles, which can be implied to promote melanogenesis. ${ }^{9}$

Many studies have found more significant pendulous melanocytes beneath melasma lesions. A Korean study in 2011 showed that prominent pendulous cells overlying the dermo-epidermal junction were found in 5 of 11 lesional skin samples and 1 of 11 perilesional normal skin samples. These cells were confirmed by immunofluorescence to be melanocytes. ${ }^{10}$ Likewise, a study from India in 2019 found that the proportion of pendulous melanocytes was significantly higher in lesional biopsies than in perilesional biopsies $(76 \%$ vs $42 \%, \mathrm{P}<0.001) .{ }^{11}$ Although these studies claimed that pendulous melanocytes were the characteristic feature of melasma, their clinical significance was unclear. It might be the prognostic factor for increasing the risk of postinflammatory hyperpigmentation followed by certain procedures, such as laser treatment.

\section{Melanophages}

Melanophages are melanin-containing macrophages found in pigmented skin lesions. They are approximately 20 to $70 \mu \mathrm{m}$ in diameter and contain a large vesicular nucleus (often with a 
single nucleolus) and phagocytized melanin in cytoplasmic granules. ${ }^{12}$ Several melanosomes are similar to the lysosomes of other organ-specific cells, such as the liver or pancreas. Active melanophages are rich in acid phosphatase, differing from active melanocytes, which are abundant in oxidative enzymes. The melanin granules of melanophages are also within phagocytic vacuole-like lysosomes, which are irregularly spheroid in shape and variable in size. ${ }^{13}$

Melanophages in melasma lesions may differ in different cases. ${ }^{14}$ Melasma lesions contain more free melanin and melanophages in the dermis (Figure 2B). In a recent study in 2019, the use of noninvasive multiphoton microscopy (MPM) to clarify melanin-containing cells within melasma lesions revealed different patterns of dermal melanophages classified by their sizes and distributions. There were four subgroups: 1 . clusters of small melanophages $(10-15 \mu \mathrm{m}), 2$. clusters of large melanophages (15-20 $\mu \mathrm{m}), 3$. dendritic melanophages, and 4. individual melanophages. The results also showed that melanophages were more commonly associated with dermal or mixed types of melasma than epidermal types. ${ }^{15}$

Few studies have shown that melanophages are not significantly increased in melasma lesions compared to perilesional areas due to the distribution variation in different cases. Nevertheless, they suggested a trend of increasing in the lesions compared to the perilesional areas. ${ }^{16}$

\section{Stem Cell Factor and c-KIT Receptor}

Stem cell factor is a growth factor that exists both as a membrane-bound and soluble form and is known as the cytokine of mitogenic factors for human melanocytes. In the dermal layer, the soluble form is more abundant. Stem cell factors can also promote the proliferation, migration, survival, and differentiation of hematopoietic progenitors or germ cells. It can stimulate the DNA synthesis of human melanocytes through tyrosine kinase ligand-receptor-mediated signal transduction pathways.

Moreover, it is known as a mast cell growth factor, steel factor, or KIT ligand. ${ }^{17}$ Mutations in stem cell factors can cause anemia, a lack of mast cells, and the disappearance of pigmentation. In our field of dermatology, stem cell factor is secreted by keratinocytes and fibroblasts, which stimulate the proliferation of human melanocytes.

The c-KIT receptor is a type III tyrosine kinase receptor involved in several diseases, such as cancer. Activation of the c-KIT receptor leads to autophosphorylation, followed by initiation of signal transduction. ${ }^{17}$ The c-KIT receptor is located on the melanocyte cell membrane and is essential in melanogenesis by activating the MAPK/ ERK cascade and then upregulating MITF expression. ${ }^{18}$

An in vitro study found that UVB light exposure can upregulate the transcription and expression of stem cell factor and c-KIT receptor within cultured human keratinocytes and melanocytes. c-KIT transcription in melanocytes was markedly increased in a dose-dependent manner at 40 $\mathrm{mJ} / \mathrm{cm}^{2}$. At the same time, stem cell factor was found more after UVB radiation within the epidermis in the stratum spinosum layer. ${ }^{19}$ Another study from Taiwan also proposed that fibroblasts with stem cell factor dysfunction affect melanocytes in melanin production under UVB stimulation. Therefore, they suggested that the role of stem cell factors secreted by fibroblasts could be a paracrine factor that functions in melanogenesis. ${ }^{20}$

In melasma lesions, several studies concluded that higher expression of stem cell factor and c-KIT receptor was more often observed within the lesional sites than in the perilesional areas. ${ }^{11,21,22}$ An increase in stem cell factor expression was reported more often in the dermis layer of the lesions, whereas in perilesional skin, its presentation was lacking, as detected by immunohistochemistry. Significantly, the increased expression was found to be greater near the dermal fibroblasts and around blood vessels. In addition, expression of c-KIT was more remarkable in melasma lesions, and c-KIT-positive basal cells, which protruded into the dermis, were also frequently observed. Moreover, the number of c-KIT-positive cells and the amount of c-KIT expressed per cell were increased in lesional skin. In addition, dermal fibroblasts were more frequently observed. ${ }^{22}$

\section{Solar Elastosis}

The term solar elastosis is characterized by the changing or aggregating of elastotic components in the dermis layer (Figure 2A). The pathophysiology of solar elastosis is not entirely clear. Chronic UV radiation, including other types of artificial light, such as incandescent and fluorescent bulbs, has been discussed as a common cause of the condition. ${ }^{23}$

The mechanism of this condition is UV radiation. Some studies reported that chronic exposure can upregulate tropoelastin mRNA gene expression in fibroblasts, producing more elastin. In contrast, chronic inflammatory cell infiltration due to repetitive exposure upregulates various proteinase enzymes known as matrix metalloproteinases (MMPs), such as collagenase and gelatinase. Therefore, these enzymes may have a role in disrupting the elastic fiber network in the dermal layer. ${ }^{24} \mathrm{In}$ addition, the role of granule release from mast cells is a factor in solar elastosis. When UV radiation activates mast cells, they 
degranulate their contents, and they bind with pro-collagenase enzymes within the dermal layer. Finally, the active form of the enzyme is created, resulting in the degradation of collagen fibers. $^{25}$

From histopathology, photodermal aging typically has been shown to involve dermal thinning due to a decrease in fibroblast number, reduced collagen synthesis, and increased UV-induced collagen degradation. ${ }^{26}$ In response to these effects, the dermal elastin network is destroyed. Consequently, elastin synthesis decreases, and the elastic fibers will become increasingly degraded. ${ }^{27}$ Finally, the degradation of fibers leads to the deposition of elastotic materials in the dermis layer. The histopathology may show only the twisted, coarse elastic fiber in the earliest stage of solar elastosis. Nevertheless, in the end, the damage could be seen as nodular basophilic or amorphous masses of accumulative materials in the upper dermis.

In some studies that showed that melasma patients had an increase in solar elastosis compared to nonaffected skin, there were abundant elastotic materials compared to nonaffected skin in a Mexican study $(13.3 \pm 2.8 \%$ vs $10.2 \pm$ $2.9 \%, \mathrm{P}<0.001)^{1}$ and significantly more severe solar elastosis in the inflammatory group than in the noninflammatory group $(2.55 \pm 0.60$ vs $4.00 \pm 0.43, \mathrm{P}<0.001)$, which was observed in a Korean study. ${ }^{21}$ Another Mexican study showed a significantly higher degree of solar elastosis in melasma skin than in perilesional skin $(83 \%$ vs $29 \%$, p < $0.05)$, and the authors discussed the correlation between solar elastosis and melasma as the cumulative sun exposure and the presence of mast cells, which may participate together and synergize their substrates and products. ${ }^{3}$

In recent years, some emerging studies suggested the term senescent fibroblasts, which refer to the aging fibroblasts as the pathophysiology of melasma. The senescent fibroblasts can be induced by the repetition of UV exposure including UVA and UVB and then secrete more melanogenic cytokines, stem cell factor (SCF), and extracellular matrix controlling factors. ${ }^{28}$ Moreover, the senescent fibroblasts have been proposed to a role in age-related pigmentary disorders such as senile lentigo. ${ }^{29}$ In parallel, melasma, which is related to the photo-aged skin, was found to have more senescent fibroblasts in the dermis compared to the perilesional normal skin while the reduction of these cells also helped in the improvement of pigmentation. ${ }^{30}$

Therefore, to challenge with sophisticated long-lasting melasma, the collection of solar elastosis and changing of fibroblast cells can diminish the pigmentation and promote skin tightening.

\section{Mast Cells}

Mast cells are inflammatory cells that mediate inflammatory responses, such as hypersensitivity or allergic reactions. They also store many different chemical mediators, such as histamine, interleukins, proteoglycans, or other enzymes, in their granules, which float within the cytoplasm. When some allergens have activated mast cells, they will begin degranulation, and chemical mediators will be released.

Many studies on the histopathology of melasma have demonstrated an increase in mast cells within the dermal layer. ${ }^{1}$ The association between the proliferation of mast cells and melasma is not entirely explicit. Mast cells can play a role in both UV-induced photoaging and melanogenesis through the mechanism of histamine and tryptase release. $^{31,32}$ Histamines are released after UV radiation exposure and bind with $\mathrm{H} 2$ receptors on melanocytes, leading to stimulation of cAMP and subsequent protein kinase A activation, inducing melanogenesis. ${ }^{31}$ Tryptase is a protease enzyme that is stored in mast cell granules. When mast cells degranulate, tryptase changes the procollagenase enzyme (proMMP-3, proMMP-1) to the active form, ${ }^{33}$ resulting in collagen fibers degradation and the skin will suffering a loss of elasticity. ${ }^{32}$

Some studies have shown that growth factors are associated with histamine-induced melanogenesis. Growth-differentiation factor 15 (GDF-15), also known as macrophage inhibitory cytokine-1, is a protein within the group of transforming growth factor-beta (TGF- $\beta$ ) that regulates the inflammatory and apoptotic pathways in injured tissues. ${ }^{34}$ An in vitro study also reported that after histamine treatment in melanocytes, expression of tyrosinase (TYR), tyrosinase-related peptide 1 (TRP-1), tyrosinase-related peptide 2 (TRP-2), and GDF-15 was increased. In contrast, when the GDF-15 gene was silenced, histamine-induced expression of tyrosinase, TRP-1 and TRP-2 was suppressed. This might imply that GDF-15 is associated with this process. Moreover, the results also emphasized histamine receptor-2 (H2-receptor), which may play a role in this complex. ${ }^{35}$

In addition, mast cells can produce angiogenesis factors or cytokines, leading to neovascularization within the melasma lesions. Mast cells release angiogenic factors by exocytosis. There are several angiogenesis cytokines, such as vascular endothelial growth factor (VEGF), fibroblast growth factor 2 (FGF-2) etc. ${ }^{36}$ 


\section{Neovascularization}

Angiogenesis is the process of new vessel creation, the process activated by angiogenic factors through endothelial cells to increase new blood vessels. Angiogenic activators, such as vascular endothelial growth factor (VEGF), basic fibroblast growth factor (bFGF), transforming growth factor (TGF)- $\alpha$ or TGF- $\beta$, platelet-derived endothelial growth factor, etc. can be generally found within normal tissue, including in the skin. Vascular endothelial growth factor (VEGF) is an essential factor in this process. In adults, the process of neovascularization is activated by VEGF-A. It can bind with several receptors, including the transmembrane tyrosine kinase receptors VEGF receptor-1 (VEGFR-1, Flt-1) and VEGF receptor-2 (VEGFR-2, flk-1/KDR). ${ }^{37}$ VEGFRs are tyrosine kinase receptors (TKRs) that play essential physiological and pathological roles in angiogenesis, especially tumor angiogenesis. After binding between vascular endothelial growth factor (VEGF) and VEGF receptor-2, the complex activates the Raf-MEKMAP kinase through a protein kinase C-dependent pathway, leading to DNA synthesis. ${ }^{38}$

VEGF production can be increased by keratinocyte activation; several factors regulate this process, such as UV radiation. After UV radiation, keratinocytes are stimulated to upregulate VEGF through multiple mechanisms. ${ }^{39}$ Surprisingly, melanocytes were found to express VEGF receptor-2, which binds more strongly with VEGF. However, some studies did not demonstrate any changes in melanocytes after complex binding, such as proliferation or differentiation. Therefore, the role of VEGF in melanocyte activation is still undetermined. ${ }^{40}$
One study observed an increase in vascular density within melasma lesions. Some pigmented lesions exhibited more intense erythema. Immunohistochemistry revealed increased vessel density and size, together with increased VEGF expression. ${ }^{41}$ From the results above, the dramatic increase in VGEF might be due to stimulation by UV radiation or other factors. In addition, VGEF plays a role in plasminogen activators, which also significantly promoted tyrosinase activity, melanocyte size, and ultimately hyperpigmentation effects. ${ }^{42}$

\section{Other Non-Skin Biopsied Tissues Images}

Although skin biopsy for histopathology is the most popular method for dermal tissue differentiation in melasma, there are several disadvantages, especially in cosmetic conditions, for example, the patients may suffer from unnecessary pain and increase the risk of scar formation. Thus, some studies tried to use the non-invasive dermal examination such as reflectance confocal microscopy (RCM) to identify the ultrastructure beneath dermal melasma.

The recent non-skin biopsy studies performed RCM and multiphoton microscopy (MPM) to evaluate the ultrastructure beneath the dermal layer of melasma. Prior to the results, RCM demonstrated a presence of melanophages, solar elastosis, and an increase in blood vessels, compared with the perilesional skin. While MPM showed only a presence of solar elastosis within the dermis (Table 2).

Table 2 The Dermal Pathology in Melasma Studies by the Non-Skin Biopsy Procedure

\begin{tabular}{|c|c|c|c|c|c|c|c|c|}
\hline \multirow[t]{2}{*}{ Authors/Country } & \multirow[t]{2}{*}{$\mathbf{N}$} & \multicolumn{2}{|c|}{ Patients } & \multicolumn{3}{|c|}{ Procedures } & \multirow[t]{2}{*}{ Result } & \multirow[t]{2}{*}{ P-value } \\
\hline & & Sex & $\begin{array}{c}\text { Skin } \\
\text { Phototype }\end{array}$ & Methods & Location & Comparison & & \\
\hline $\begin{array}{l}\text { Kang et al (2010) } \\
\text { France }^{43}\end{array}$ & 26 & No data & Type II-V & $\mathrm{RCM}$ & Face & $\begin{array}{l}\text { Perilesional } \\
\text { areas }\end{array}$ & $\begin{array}{l}\text { - Increased melanophages } \\
\text { - Solar elastosis } \\
\text { - Increased blood vessels }\end{array}$ & $\begin{array}{l}0.001 \\
0.006 \\
0.038\end{array}$ \\
\hline $\begin{array}{l}\text { Costa et al }(2012) \\
\text { Brazil }^{44}\end{array}$ & I & Female & Type IV & RCM & Face & None & - Melanophages & $\mathrm{N} / \mathrm{A}$ \\
\hline $\begin{array}{l}\text { Lentsch et al (2019) } \\
\text { USA }^{15}\end{array}$ & 12 & Female & Type III-V & MPM & Face & $\begin{array}{l}\text { Perilesional } \\
\text { areas }\end{array}$ & $\begin{array}{l}\text { - Higher pigment amount in } \\
\text { lesional skin epidermis } \\
\text { - Increased solar elastosis }\end{array}$ & $\begin{aligned} & 0.03 \\
< & 0.001\end{aligned}$ \\
\hline $\begin{array}{l}\text { Zeng et al (2020) } \\
\text { China }^{45}\end{array}$ & 196 & $\begin{array}{c}163 \\
\text { Female }\end{array}$ & No data & RCM & Face & Normal skin & - Melanophages & N/A \\
\hline
\end{tabular}

Abbreviations: MPM, multiphoton microscopy; N/A, not available; RCM, reflectance confocal microscopy. 
Table 3 Clinical Application from Dermal Changes in Melasma

\begin{tabular}{|l|l|c|}
\hline $\begin{array}{l}\text { Dermal Changes in } \\
\text { Melasma }\end{array}$ & \multicolumn{1}{|c|}{ Specific Agents or Modalities } & References \\
\hline $\begin{array}{l}\text { Pendulous or hyperactive } \\
\text { melanocytes }\end{array}$ & $\begin{array}{l}\text { - Whitening agents such as hydroquinone, azelaic acid, arbutin, licorice extract, linoleic acid, lignin } \\
\text { peroxidase etc. }\end{array}$ & [46] \\
\hline Solar elastosis & $\begin{array}{l}\text { - Topical retinoids } \\
\text { - Energy based devices such as fractional 2940-nm erbium:YAG, Low-fluence I064-nm Q-switch } \\
\text { ND:YAG, I550-nm erbium glass laser }\end{array}$ & [47] \\
\hline Mast cells & $\begin{array}{l}\text { - Zinc } \\
\text { - Tranexamic acid } \\
\text { - Topical anti-histamine }\end{array}$ & [48,49] \\
\hline Neovascularization & $\begin{array}{l}\text { - Tranexamic acid } \\
- \text { Pulse dyed laser }\end{array}$ & \\
\hline
\end{tabular}

Abbreviations: ND:YAG, neodymium-doped yttrium aluminium garnet; nm, nanometer.

\section{Further Clinical Application from Dermal Changes in Melasma}

Due to the complex pathophysiology of melasma, the condition may need some distinctive agents or modalities to be tackled. Regarding the treatments of melasma, there are some targets of dermal changes in melasma, which have been up-to-date discovered to have a benefit for instance; pendulous and hyperactive melanocytes, solar elastosis, mast cells, and neovascularization (Table 3).

\section{Conclusion}

Histopathological changes in the dermis, including basement membrane disruption, pendulous melanocytes, melanophages, mast cells, stem cell factor and c-KIT receptor, solar elastosis, and neovascularization, may play a role in the pathogenesis of melasma. These findings could serve as potential target treatments since this condition is often recalcitrant and requires a multimodal approach. According to this review, the specific dermal changes of melasma in the aspect of treatments can be divided into hyperactive melanocytes, solar elastosis, mast cells, and neovascularization. For hyperactive melanocytes, some conventional and novel anti-tyrosinase agents can be helpful. Retinoids and energy-based devices such as fractional 2940-nm erbium:YAG, Low-fluence 1064-nm Q-switch ND: YAG, 1550-nm erbium glass laser may collect and restore solar elastosis. While mast cells and neovascularization are regressed by the tranexamic acid and pulse dyed laser, respectively. Including primitive agents, anti-histamine may inhibit the effect of mast cells. However, further studies regarding the efficacy of each modality in the treatment of dermal melasma may need more investigated.

\section{Acknowledgments}

We thank Dr.Suthep Jirasuthat for providing the histological picture of melasma.

\section{Disclosure}

The authors report no conflicts of interest in this work.

\section{References}

1. Hernández-Barrera R, Torres-Alvarez B, Castanedo-Cazares JP, OrosOvalle C, Moncada B. Solar elastosis and presence of mast cells as key features in the pathogenesis of melasma. Clin Exp Dermatol. 2008;33 (3):305-308. doi:10.1111/j.1365-2230.2008.02724.x

2. Sanchez NP, Pathak MA, Sato S, Fitzpatrick TB, Sanchez JL, Mihm MC Jr. Melasma: a clinical, light microscopic, ultrastructural, and immunofluorescence study. J Am Acad Dermatol. 1981;4(6):698710. doi:10.1016/S0190-9622(81)70071-9

3. Torres-Álvarez B, Mesa-Garza IG, Castanedo-Cázares JP, et al. Histochemical and immunohistochemical study in melasma: evidence of damage in the basal membrane. Am J Dermatopathol. 2011;33 (3):291-295. doi:10.1097/DAD.0b013e3181ef2d45

4. Shin JH, Kang WH. Two cases of melasma with unusual histopathologic findings. J Korean Med Sci. 2006;21(2):368-370. doi:10.3346/ jkms.2006.21.2.368

5. Inomata S, Matsunaga Y, Amano S, et al. Possible involvement of gelatinases in basement membrane damage and wrinkle formation in chronically ultraviolet B-exposed hairless mouse. J Invest Dermatol. 2003;120(1):128-134. doi:10.1046/j.1523-1747.2003.12021.x

6. Kim NH, Choi SH, Lee TR, Lee CH, Lee AY. Cadherin 11 involved in basement membrane damage and dermal changes in melasma. Acta Derm Venereol. 2016;96(5):635-640. doi:10.2340/000155552315

7. Herlyn M, Berking C, Li G, Satyamoorthy K. Lessons from melanocyte development for understanding the biological events in naevus and melanoma formation. Melanoma Res. 2000;10(4):303-312. doi:10.1097/00008390-200008000-00001

8. Bacharach-Buhles M, Lubowietzki M, Altmeyer P. Dose-dependent shift of apoptotic and unaltered melanocytes into the dermis after irradiation with UVA 1. Dermatology. 1999;198(1):5-10. doi: $10.1159 / 000018056$ 
9. Ortonne JP, Claudy AL, Freycon F. Café au lait spots in ataxiatelangiectasia (A.T.). Histochemical and ultrastructural study in one case. Arch Dermatol Res. 1980;268(1):91-99. doi:10.1007/ BF00403891

10. Lee DJ, Park KC, Ortonne JP, Kang HY. Pendulous melanocytes: a characteristic feature of melasma and how it may occur. Br J Dermatol. 2012;166(3):684-686. doi:10.1111/j.1365-2133.2011.10648.x

11. Gautam M, Patil S, Nadkarni N, Sandhu M, Godse K, Setia M. Histopathological comparison of lesional and perilesional skin in melasma: a cross-sectional analysis. Indian J Dermatol Venereol Leprol. 2019;85(4):367-373. doi:10.4103/ijdvl.IJDVL_866_17

12. Guitera P, Li LX, Scolyer RA, Menzies SW. Morphologic features of melanophages under in vivo reflectance confocal microscopy. Arch Dermatol. 2010;146(5):492-498. doi:10.1001/archdermatol.2009.388

13. Mishima Y. Cellular and subcellular differentiation of melanin phagocytosis and synthesis by lysosomal and melanosomal activity. $J$ Invest Dermatol. 1966;46(1):70-75. doi:10.1038/jid.1966.11

14. Liu H, Lin Y, Nie X, et al. Histological classification of melasma with reflectance confocal microscopy: a pilot study in Chinese patients. Skin Res Technol. 2011;17(4):398-403. doi:10.1111/j.16000846.2011.00517.x

15. Lentsch G, Balu M, Williams J, et al. In vivo multiphoton microscopy of melasma. Pigment Cell Melanoma Res. 2019;32(3):403411. doi: $10.1111 / \mathrm{pcmr} .12756$

16. Grimes PE, Yamada N, Bhawan J. Light microscopic, immunohistochemical, and ultrastructural alterations in patients with melasma. Am J Dermatopathol. 2005;27(2):96-101. doi:10.1097/01. dad.0000154419.18653.2e

17. Lennartsson J, Rönnstrand L. Stem cell factor receptor/c-Kit: from basic science to clinical implications. Physiol Rev. 2012;92(4):16191649. doi:10.1152/physrev.00046.2011

18. Hemesath TJ, Price ER, Takemoto C, Badalian T, Fisher DE. MAP kinase links the transcription factor Microphthalmia to c-Kit signalling in melanocytes. Nature. 1998;391(6664):298-301. doi:10.1038/ 34681

19. Hachiya A, Kobayashi A, Ohuchi A, Takema Y, Imokawa G. The paracrine role of stem cell factor/c-kit signaling in the activation of human melanocytes in ultraviolet-B-induced pigmentation. $J$ Invest Dermatol. 2001;116(4):578-586. doi:10.1046/j.15231747.2001.01290.x

20. Li PH, Liu LH, Chang CC, et al. Silencing stem cell factor gene in fibroblasts to regulate paracrine factor productions and enhance c-kit expression in melanocytes on melanogenesis. Int J Mol Sci. 2018;19 (5):1475. doi:10.3390/ijms 19051475

21. Noh TK, Choi SJ, Chung BY, et al. Inflammatory features of melasma lesions in Asian skin. $J$ Dermatol. 2014;41(9):788-794. doi:10.1111/1346-8138.12573

22. Kang HY, Hwang JS, Lee JY, et al. The dermal stem cell factor and c-kit are overexpressed in melasma. Br J Dermatol. 2006;154 (6):1094-1099. doi:10.1111/j.1365-2133.2006.07179.x

23. Romanhole RC, Ataide JA, Moriel P, Mazzola PG. Update on ultraviolet $\mathrm{A}$ and $\mathrm{B}$ radiation generated by the sun and artificial lamps and their effects on skin. Int $J$ Cosmet Sci. 2015;37(4):366-370. doi:10.1111/ics.12219

24. Seo JY, Lee SH, Youn CS, et al. Ultraviolet radiation increases tropoelastin mRNA expression in the epidermis of human skin in vivo. J Invest Dermatol. 2001;116(6):915-919. doi:10.1046/j.15231747.2001.01358.x

25. Krejci NC, Knapp DM, Rudd RJ, Bauer EA, McGuire J. Dermal mast cell granules bind interstitial procollagenase and collagenase. $J$ Invest Dermatol. 1992;98(5):748-752. doi:10.1111/1523-1747. ep12499942

26. Tsukahara K, Tamatsu Y, Sugawara Y, Shimada K. Morphological study of the relationship between solar elastosis and the development of wrinkles on the forehead and lateral canthus. Arch Dermatol. 2012;148(8):913-917. doi:10.1001/archdermatol.2012.157
27. Godeau G, Hornebeck W. Morphometric analysis of the degradation of human skin elastic fibres by human leukocyte elastase (EC 3-4-2137) and human skin fibroblast elastase (EC 3-4-24). Pathol Biol. 1988;36(9):1133-1138.

28. Shin J, Kim JH, Kim EK. Repeated exposure of human fibroblasts to UVR induces secretion of stem cell factor and senescence. $J$ Eur Acad Dermatol Venereol. 2012;26(12):1577-1580. doi:10.1111/ j.1468-3083.2011.04223.x

29. Yoon JE, Kim Y, Kwon S, et al. Senescent fibroblasts drive ageing pigmentation: a potential therapeutic target for senile lentigo. Theranostics. 2018;8(17):4620-4632. doi:10.7150/thno.26975

30. Kim M, Kim SM, Kwon S, Park TJ, Kang HY. Senescent fibroblasts in melasma pathophysiology. Exp Dermatol. 2019;28(6):719-722.

31. Yoshida M, Takahashi Y, Inoue S. Histamine induces melanogenesis and morphologic changes by protein kinase A activation via $\mathrm{H} 2$ receptors in human normal melanocytes. $J$ Invest Dermatol. 2000;114(2):334-342. doi:10.1046/j.1523-1747.2000.00874.x

32. Iddamalgoda A, Le QT, Ito K, Tanaka K, Kojima H, Kido H. Mast cell tryptase and photoaging: possible involvement in the degradation of extra cellular matrix and basement membrane proteins. Arch Dermatol Res. 2008;300(Suppl 1):S69-76. doi:10.1007/s00403-0070806-1

33. Suzuki K, Lees M, Newlands GF, Nagase H, Woolley DE. Activation of precursors for matrix metalloproteinases 1 (interstitial collagenase) and 3 (stromelysin) by rat mast-cell proteinases I and II. Biochem J. 1995;305(Pt 1):301-306. doi:10.1042/bj3050301

34. Wischhusen J, Melero I, Fridman WH. Growth/differentiation factor15 (GDF-15): from biomarker to novel targetable immune checkpoint. Front Immunol. 2020;11:951. doi:10.3389/fimmu.2020.00951

35. Lee HJ, Park MK, Lee EJ, et al. Histamine receptor 2-mediated growth-differentiation factor-15 expression is involved in histamineinduced melanogenesis. Int J Biochem Cell Biol. 2012;44(12):21242128. doi:10.1016/j.biocel.2012.08.020

36. Theoharides TC, Kempuraj D, Tagen M, Conti P, Kalogeromitros D. Differential release of mast cell mediators and the pathogenesis of inflammation. Immunol Rev. 2007;217(1):65-78. doi:10.1111/j.1600065X.2007.00519.X

37. Petrova TV, Makinen T, Alitalo K. Signaling via vascular endothelial growth factor receptors. Exp Cell Res. 1999;253(1):117-130. doi:10.1006/excr.1999.4707

38. Shibuya M.Vascular Endothelial Growth Factor (VEGF) and Its Receptor (VEGFR) signaling in angiogenesis: a crucial target for anti- and pro-angiogenic therapies. Genes Cancer. 2011;2(12):10971105. doi:10.1177/1947601911423031

39. Kosmadaki MG, Yaar M, Arble BL, Gilchrest BA. UV induces VEGF through a TNF-alpha independent pathway. FASEB $J$. 2003;17(3):446-448. doi:10.1096/fj.02-0379fje

40. Kim EJ, Park HY, Yaar M, Gilchrest BA. Modulation of vascular endothelial growth factor receptors in melanocytes. Exp Dermatol. 2005;14(8):625-633. doi:10.1111/j.0906-6705.2005.00345.x

41. Kim EH, Kim YC, Lee ES, Kang HY. The vascular characteristics of melasma. J Dermatol Sci. 2007;46(2):111-116. doi:10.1016/j. jdermsci.2007.01.009

42. Pepper MS, Ferrara N, Orci L, Montesano R. Vascular endothelial growth factor (VEGF) induces plasminogen activators and plasminogen activator inhibitor-1 in microvascular endothelial cells. Biochem Biophys Res Commun. 1991;181(2):902-906. doi:10.1016/0006291X(91)91276-I

43. Kang HY, Bahadoran P, Suzuki I, et al. In vivo reflectance confocal microscopy detects pigmentary changes in melasma at a cellular level resolution. Exp Dermatol. 2010;19(8):e228-233. doi:10.1111/j.16000625.2009.01057.x

44. Costa MC, Eljaiek HV, Abraham LS, Azulay-Abulafia L, Ardigo M. In vivo reflectance confocal microscopy in a typical case of melasma. An Bras Dermatol. 2012;87(5):782-784. doi:10.1590/S036505962012000500021 
45. Zeng X, Qiu Y, Xiang W. In vivo reflectance confocal microscopy for evaluating common facial hyperpigmentation. Skin Res Technol. 2020;26(2):215-219. doi:10.1111/srt.12782

46. Draelos ZD. A split-face evaluation of a novel pigment-lightening agent compared with no treatment and hydroquinone. J Am Acad Dermatol. 2015;72(1):105-107. doi:10.1016/j.jaad.2014.09.011

47. Griffiths CE, Finkel LJ, Ditre CM, Hamilton TA, Ellis CN, Voorhees JJ. Topical tretinoin (retinoic acid) improves melasma. A vehiclecontrolled, clinical trial. Br J Dermatol. 1993;129(4):415-421. doi:10.1111/j.1365-2133.1993.tb03169.x

48. Sharquie KE, Al-Mashhadani SA, Salman HA. Topical 10\% zinc sulfate solution for treatment of melasma. Dermatol Surg. 2008;34 (10):1346-1349. doi:10.1111/j.1524-4725.2008.34287.x
49. Na JI, Choi SY, Yang SH, Choi HR, Kang HY, Park KC. Effect of tranexamic acid on melasma: a clinical trial with histological evaluation. J Eur Acad Dermatol Venereol. 2013;27(8):1035-1039. doi:10.1111/j.1468-3083.2012.04464.x

50. Fioranelli M, Jafferany M, Wollina U, Tirant M, Van Thuong N, Lotti T. New local treatments for different types of melasma: vascular type vs nonvascular type. A randomized polycentric study. Dermatol Ther. 2020;33(3):e13300. doi:10.1111/dth.13300

51. Passeron T, Fontas E, Kang HY, Bahadoran P, Lacour JP, Ortonne JP. Melasma treatment with pulsed-dye laser and triple combination cream: a prospective, randomized, single-blind, split-face study. Arch Dermatol. 2011;147(9):1106-1108. doi:10.1001/archdermatol.2011.255

\section{Publish your work in this journal}

Clinical, Cosmetic and Investigational Dermatology is an international, peer-reviewed, open access, online journal that focuses on the latest clinical and experimental research in all aspects of skin disease and cosmetic interventions. This journal is indexed on CAS.
The manuscript management system is completely online and includes a very quick and fair peer-review system, which is all easy to use. Visit http://www.dovepress.com/testimonials.php to read real quotes from published authors. 